\title{
Proposal of Methodology and Test Protocol for Evaluating and Qualifying pH Measuring Devices
}

\author{
Niza Helena de Almeida and Percy Nohama* \\ ${ }^{1}$ Pontifícia Universidade Católica do Paraná - PUCPR; Programa de Pós Graduação em Tecnologia em Saúde; \\ Rua Imaculada Conceição, 1155; percy@ppgia.pucpr.br; 80215-901 - Curitiba - PR - Brasil
}

\begin{abstract}
We present a proposal for evaluating and qualifying $\mathrm{pH}$ measuring devices based on the requirements of relevant standards. The proposal presented is based on ASTM E70, NBR 7353, JIS Z 8805, BS 3145, DIN 19268, NBR ISO 17025 and other standards, as well as the results of field research carried out in conjunction with professionals performing $\mathrm{pH}$ measurements in public health laboratories. Evaluation is performed by inspection of a form which records data from the measuring system. The form gives acceptable variations in the parameters being tested and allows a conclusion to be reached regarding acceptability of the system. Using the proposed protocol allows definition of suitable analysis criteria, while taking into account the influence pH measurement is subject and the need for correct results. This is particularly true when analyzing products already on the market, thus underlining the protocol's importance to the public health area.
\end{abstract}

Key words: Quality control, $\mathrm{pH}$ measurement, instrumentation

\section{INTRODUCTION}

The degree of acidity or alkalinity of a substance is determined by $\mathrm{pH}$ measurement. This measurement can be carried out using the potentiometric method, in which the $\mathrm{pH}$ meter measures the electrical potential difference between the reference electrode and the glass membrane of an indicating electrode immersed in the sample in which the $\mathrm{pH}$ value is being analyzed. The choice of the measuring method depends on the desired accuracy (ABNT, 1989; ASTM, 2002).

Waddel and Bates (1969) state that knowledge of the degree of acidity in chemical systems is so relevant that it is imperative to have agreement between the definition of $\mathrm{pH}$ and the standardization adopted in practical measurement.
Without such agreement, it would be impossible to make comparison between measurements carried out in different laboratories or in the same laboratory on a daily basis. Buck et al. (2002) report that, as $\mathrm{pH}$ is a conventional quantity, determination of its magnitude is based on a series of standard buffer solutions. For $\mathrm{pH}$ evaluation, uncertainties and requirements must be defined for each specific case. Accurate $\mathrm{pH}$ measurements are needed in a number of different routine situations encountered in the food, cosmetics and pharmaceutical industries.

The importance of high accuracy on $\mathrm{pH}$ measurement is illustrated by the case of canned preserved palm heart, which is considered to be the main cause of botulism outbreaks in Brazil, Law n. 304, 1999 (ANVISA, 1999) and for which the Ministry of Health - National Health

\footnotetext{
${ }^{*}$ Author for correspondence
} 
Surveillance Agency (ANVISA), determined a $\mathrm{pH}$ value of 4.50, in Resolution n. 362, 1999 (ANVISA, 1999).

Based on a specific concern about the production of medicines, ANVISA's Resolution n. 210 prescribes quality control standards/ procedures for equipment used during the manufacturing processes and requires the existence of documentary evidence that the desired results have been attained. According to this standard, quality control of equipment consists of a set of operations that determine, under predefined conditions, whether the results of the tests on a specific piece of equipment show that they have the expected performance.

The need for qualification extends to $\mathrm{pH}$ meters, as they are an integral part of many stages of medicine manufacturing process; if the measured values are inadequate, this may have an impact on the quality, safety, stability and effectiveness of the final product released in the market. In this context, this paper presents a methodology and a proposal for a protocol to evaluate and qualify $\mathrm{pH}$ measuring devices according to the requirements established by relevant standards, with a view to establishing legal requirements for $\mathrm{pH}$ determination. It also proposes parameters that should be evaluated to ensure adequate performance of the measuring system and reliable results. The proposal is primarily based on requirements of ASTM E70 (2002) and NBR 7353 (1989), complemented by JIS Z 8805 (1989), BS 3145 (1993), DIN 19268 (1985), NBR ISO 17025 (2001); BS 1647: Part 2 (1984), DIN 19260 (1971), DIN 19263 (1899), DIN 19265 (1994), DIN 19266 (2000), DIN 19267 (1978) and GOST 8134 (1999), and also based on results of field research carried out in conjunction with professionals performing $\mathrm{pH}$ test measurements in public health laboratories.

\section{MATERIALS AND METHODS}

In order to define a methodology and create a protocol for final evaluation in agreement with the standards relating to $\mathrm{pH}$ measurement systems, Brazilian and international standards were chosen and then evaluated. When carrying out the evaluation, common ground was sought between the actual reality of the work carried out in laboratories where $\mathrm{pH}$ measurements are undertaken and the requirements highlighted by the standards that were evaluated.

The reality in laboratories was evaluated through a questionnaire prepared and sent to public health institutions in each state of Brazil. As requested, the questionnaires were answered by technical staff involved in $\mathrm{pH}$ measurement procedures.

The content of the equipment manuals was also evaluated in order to verify whether the manufacturers supply the user with appropriate information, and if there is consistency between different manuals. Thus, the protocol was drawn up and its structure divided into the following subjects: general data, data on the tested instruments, visual inspection of the meter and electrodes, buffer solution data, electrode data, meter, electrode and temperature sensor performance tests, and a conclusion regarding the status of the meter. Each item is related to a standard, as described below.

Initially, the institution and details related to the instrument and electrodes are identified, such as name of the manufacturer, model, serial number and controls, as prescribed by NBR ISO 17025 and DIN 19263 standards (ABNT, 2001; DIN, 1989).

The technical form is filled in based on visual inspection of the meter and electrodes; evaluation, by means of documentation of the other instruments required to carry out the qualifying tests, calibration certificates, the existence of a manual, and environmental conditions. The form also allows for details of supplies and instruments used to calibrate the $\mathrm{pH}$ meter and the source of the buffer solutions to be included, as well as ensuring traceability. The word "calibrate" and its compounds, as required by DIN 19267 and BS 3145 standards, do not have the meaning, in the context discussed here, of official calibration by a calibrating authority or institution (DIN, 1978; $\mathrm{BS}, 1993)$. With regard to $\mathrm{pH}$ meter performance, ASTM E 70 and NBR 7353 standards prescribe the requirement to differentiate between electrode performance and meter performance. They state that the term "meter" only applies to the instrument for measuring potential (in $\mathrm{mV}$ or $\mathrm{pH}$ ), "electrode" applies to the measuring electrodes and "device" applies to "meter and electrodes" together (ABNT, 1989; ASTM, 2002). As the measurement of $\mathrm{pH}$ has an impact on the quality of a large number of products, and as there is a range of standards on the subject covering a number of different parameters, the protocol aims to bring 
together the main recommendations encountered. However, it does not aim to exhaust all possible approaches, but leaves it instead to the user of the $\mathrm{pH}$ meter to seek out more detailed and specific information to complement the proposals. As far as performance of the $\mathrm{pH}$ meter is concerned, the proposal drawn up is based on ASTM E 70, JIS Z 8805, DIN 19268 and NBR 7353 standards, which prescribe a maximum variation of $1 \mathrm{mV}$ in the performance of the meter (electrical balancing) per increment (ASTM, 2002; JIS, 1989; DIN, 1985; ABNT, 1989).

ASTM E 70 and NBR 7353 standards refer to such requirements in situations where accuracy of measurement is required, such as in litigation, when the equipment needs to detect $\mathrm{pH}$ changes of 0.01 units $(0.6 \mathrm{mV})$ or less. BS 1647 (Part 2) standard states that the accuracy of the $\mathrm{pH}$ of a sample depends on the maximum error permitted in a particular case (BS, 1984). This applies to tests to measure $\mathrm{pH}$ in products under health surveillance and other products with such requirements.

In order to evaluate the performance of the electrode system, ASTM E 70 and NBR 7353 standards prescribe a group of standard buffer solutions that are traceable to the National Institute of Science and Technology (NIST). Thus, values are specified according to the type of electrode they are going to be used with. Standard buffer solutions are defined in DIN 19260 as solutions with a fixed composition for evaluating the $\mathrm{pH}$ scale and which bring the $\mathrm{pH}$ meter to its setting points (DIN, 1971). Buffer solutions must meet a number of requirements, such as those relating to storage conditions and susceptibility to certain environmental conditions, in order to meet their intended purpose as prescribed by DIN 19266 standard (DIN, 2000).

A-A-53018 standard states that labeling of buffer solutions must identify the substance and the permitted variation, as well as allowing the contents to be seen (GSA, 1987). Buffer solutions must be clear and must not have undergone any changes that might adversely affect their performance as prescribed by A-A53206 standard (GSA, 1987). The JIS K 0018 standard deals with manufacture of buffer solutions and states that the packaging must indicate they need to be kept at $25^{\circ} \mathrm{C}$ or less before they are opened, but cannot be frozen (JIS, 1997).

Under the item electrodes for general use, ASTM E 70 and NBR 7353 standards prescribe $\mathrm{pH}$ buffers with values below 9.18 at $25^{\circ} \mathrm{C}$ and state that carbonate buffer and borax buffer are suitable for evaluating "high alkalinity" type electrodes, with tests being complemented with the use of sodium hydroxide solution with $\mathrm{pH}$ equal to 12.8 (ASTM, 2002; ABNT, 1989). These standards also establish the acceptable variations and prescribe the use of high alkalinity electrodes for samples with $\mathrm{pH}$ supposedly greater than 10.0. JIS Z 8805 standard also prescribes borate and sodium hydroxide solutions for evaluating the alkaline error in glass electrodes and specifies acceptable limits for potential differences, in $\mathrm{mV}$ (JIS, 1989). The electrolyte used to measure $\mathrm{pH}$ plays a very relevant role, as it is responsible for the electrolytic bridge between sample and meter. Its concentration is regulated by the BS 1647: Part 2 and GOST 8134 standards. Both standards prescribe the use of $\mathrm{KCI}$ at a $3.5 \mathrm{M}$ concentration as a reference electrolyte. Other standards, however, prescribe concentrations of at least $3.0 \mathrm{M}$ (BS, 1984; GOST, 1999; DIN, 1978). The JIS Z 8805 standard classifies electrodes (glass and reference ones) according to the temperature range for which they are suitable and prescribe specific tests to evaluate performance in the respective temperature ranges (JIS, 1989). Temperature is an important parameter when measuring $\mathrm{pH}$ (Karlsson and Rosenvold, 2002).

To achieve the desired degree of consistency once the instrument has been calibrated, $\mathrm{pH}$ measurements of unknown samples or of buffer solutions must be carried out in triplicate, as specified in JIS Z 8805 standard (JIS, 1989). Referring to calibration, DIN 19268 states that this must be done in two points and that a primary standard is not necessary to achieve the desired adjustment of the system (DIN, 1985). With regard to $\mathrm{pH}$ measurements in the blood, the A-A-53018 standard prescribes calibration in three points using buffer of 4.0, 7.0 and 10.0 (GSA, 1987). Some standards also refer to the permitted variation in tests to measure $\mathrm{pH}$, for example, the GOST 8134 and A-A-53018 standards (GOST, 1999; GSA, 1987). In the proposal presented here, we suggest calibration in at least three points, considering the need for measurements in both strongly acidic and strongly alkaline solutions. According to Illingworth (1981) and Naumann et al. (2002), however, consistently accurate measurements are achieved by calibrating in multiple points, when results with minimum uncertainty and maximum reliability are desired. 
DIN 19263 standard prescribes the parameters for identification of the electrodes, such as serial number, $\mathrm{pH}$ range, temperature range, zero point, type of reference electrode with which the electrode should be used $(\mathrm{pH} 0.0$ to $12.0 ; 0$ to $70^{\circ} \mathrm{C} ; 7.0 \mathrm{Ag}$, which means that the electrode is suitable for use in a pH range between 0 and 12; the temperature of the solution being analyzed is in the range 0 to $70{ }^{\circ} \mathrm{C}$; its zero point is found in $\mathrm{pH}$ equal to $7.0 \pm 0.5$; and that its reference system is $\mathrm{Ag} / \mathrm{AgCl})$. The standard states that measurement of the zero point of the electrode must be specified at 7.0 or 4.6 and this information shall appear on the body of the electrode (DIN, 1989). The type of temperature sensor connected to the device must also be identified indelibly. In addition, BS 3145 and JIS K 0018 standards specify a thermostatized bath and allowed variations in temperature for $\mathrm{pH}$ tests (BS, 1993; JIS, 1997).

DIN19265 standard prescribes the requirements for the meter, such as operating conditions, markings, connection terminals and sensitivity adjustments (DIN, 1994). The BS 3145 standard, on the other hand, specifies the requirements for meters for laboratory use, and deals with the way the measurements are displayed on the instrument scale and the requirements for the scale, display errors, thermal stability, correction errors, performance and conformance tests, instrument calibration, the need for specific devices for this type of equipment, and tests to check that the requirements are being met (BS, 1993). Based on the information described, we drew up a protocol in such a way as to ensure that the person using it evaluates the measuring system appropriately and analyzes its status so that reliable $\mathrm{pH}$ measurements can be obtained.

\section{RESULTS}

The inspection form created to evaluate the $\mathrm{pH}$ measuring device is suited to the reality of routine laboratories, as $86 \%$ of its content consists of tests based on visual inspection of the equipment, evaluation of the manufacturer's manual, evaluation of the supplies, and tests to measure $\mathrm{pH}$, which differ from routine tests in the sample used, namely a buffer solution with a known $\mathrm{pH}$ value.

The remainder of the recommended tests requires an instrument for simulating $\mathrm{pH}$ and potential difference $(\mathrm{mV})$. These tests can be carried out by qualified companies hired to carry out the procedure under the supervision and guidance of the person responsible for the instrument in the laboratory. Based on an evaluation of the relevant standards, it was established that the protocol should consist of pre-established requirements that ensure knowledge of the status of the system. The proposed protocol covers eight main topics. Within these, a number of specific requirements are addressed in order to meet the requirements of the standards evaluated.

The following results were obtained in the field work carried out:

1. $66 \%$ of the technicians use combined electrodes to measure $\mathrm{pH}$ during routine laboratory work;

2. $85 \%$ of the technicians calibrate the equipment in two points and do not consider strongly alkaline solutions;

3. $51 \%$ of the technicians involved in the tests have never received any general training in the use of the instrument and 54\% have not received any specific training;

4. $56 \%$ consider the content of the equipment manuals to be insufficient;

5. $15 \%$ declare that they store buffer solutions at room temperature;

6. $81 \%$ of the technicians that took part in the study consider $\mathrm{pH}$ measurement testing to be a simple procedure;

7. $46 \%$ of the technicians declare that they do not evaluate the performance of the system temperature sensor;

8. no reference was made to the need for, or the practice of, carrying out tests to check the performance of the meter.

\section{DISCUSSION}

The proposed protocol provides a practical and effective way to evaluate $\mathrm{pH}$ measuring devices. Both the technical specifications and operational status of the instrument can be observed and preventive maintenance can be registered and stored for historical data retrieval.

The procedure allows data about the instrument to be brought together, thus providing documentation that can form the basis of historical records which may be useful for the supplier and ease the attendance of A-A-53206 standard requirements (GSA, 1987). This standard specifies that data concerning equipment calibration should be kept for 3 years. The procedure also allows selection 
criteria to be established for equipment, electrodes, and buffer solutions at the time of purchase.

The $\mathrm{pH}$ measurement discussed here regarding a potentiometric - based $\mathrm{pH}$ measuring instrument should be included in a group of laboratory tests that are subject to stringent procedures when carried out, bearing in mind the potential sources of interference that may cause significant errors (discrepancies) in the final result, and the importance of the results for terms public health.

The field research carried out showed that combined electrodes have been used for measuring $\mathrm{pH}$ during routine laboratory work in the majority of public laboratories. This type of electrode, however, is considered a possible source of nonconformity in $\mathrm{pH}$ measurements (Illingworth, 1981; Naumann et al., 2002). It was also observed that meters are calibrated in two points and those measurements of $\mathrm{pH}$ in the alkaline range are not a souce of concern, according to the majority ( $85 \%$ ) of respondents.

Illingworth (1981) states that common errors in combined electrodes are not detected during conventional calibration procedure using only two or three points. It is thus imperative that technicians carrying out the measurements shall be qualified, with specific training, and that they should be aware of any interfering factors, as well as procedures for obtaining consistent results. It was also observed that some technicians involved in tests have received neither general nor specific training for carrying out $\mathrm{pH}$ tests, which is reflected in the casual approach to this type of measurement.

Another significant factor is that none of the respondents mentioned the need for, or knowledge of, tests to check the performance of the meter. In addition, a large proportion of those queried (46\%) do not check the conformance of the system temperature sensor, despite this factor being considered relevant to this type of test, since ionic activity is being evaluated (Karlsson and Rosenvold, 2002). Most of those interviewed (81\%) stated that they considered $\mathrm{pH}$ measuring to be a simple process which indeed it is in terms of execution, but complex in terms of the electrochemical factors involved and the importance of the final result for the parameter in specific situations, such as in the case of litigation (ASTM E 70,2002; NBR 7353, 1989).

The user manuals supplied by the manufacturers were found to be lacking important information about the electrodes and buffer solutions. Many of the requirements mentioned in the relevant standards are not mentioned in the manuals, and the majority of electrodes evaluated do not even have the name of the manufacturer on them. According to the JIS K 0018 standard, the storage temperature for buffer solutions must be kept below $25^{\circ} \mathrm{C}$, but above freezing temperature (JIS, 1997). A number of technicians, however, stated that they store buffer solutions at room temperature, and do not confirm the laboratory has air-conditioning. Many of the laboratories are in areas where the temperature exceeds the $25{ }^{\circ} \mathrm{C}$ laid down in the standard.

Incorrect $\mathrm{pH}$ values can lead to the release of lowquality or unqualified products into the consumer market, or in restrictions being imposed upon, or even prohibition of, a product that meets all the required technical specifications.

\section{CONCLUSIONS}

Regulation of the requirements evaluated in the protocol, from inspection of the instrument to the results of test measurements, provides data which guarantees the conformance of the instrument at the time the tests are carried out. It also assists when qualifying suppliers of $\mathrm{pH}$ meters, electrodes and buffer solutions, in so far as certain suppliers may present a specific type of deviation. It will therefore be possible to evaluate a supplier's response in terms of the extent to which they solve occasional problems, as well as providing reliable measurement results.

It is hoped that benefits will arise from the incorporation of the methodology created, and the developed protocol, into laboratory equipment management plans, as this will result in an additional tool to help reaching the quality requirements for tests within a laboratory's quality management system.

\section{RESUMO}

Este artigo apresenta uma proposta de protocolo de avaliação e qualificação de medidores de $\mathrm{pH}$ fundamentada no que prescrevem as normas ASTM E 70, NBR 7353, JIS Z 8805, BS 3145, DIN 19268, NBR ISO 17025 e outras, complementada com os resultados de pesquisa de campo junto a profissionais que realizam ensaio de 
medição de $\mathrm{pH}$ em laboratórios de saúde pública. A proposta consiste em avaliar o medidor de $\mathrm{pH}$ com auxílio de um formulário, cujo preenchimento baseia-se, principalmente, na inspeção e ensaios no sistema medidor. $\mathrm{O}$ formulário fornece variações aceitáveis para os parâmetros testados, propiciando parecer conclusivo quanto à adequação do instrumento. A aplicação do protocolo permite definir um critério adequado de análise, tendo em vista a influência que sofre tal ensaio de medição, especialmente, em análises de amostras de produtos decorrentes de finalidade fiscal, no âmbito da saúde pública.

\section{REFERENCES}

[1] ASTM (2002), ASTM E70-97: Standard test method for $\mathrm{pH}$ aqueous solution with the glass electrode. USA: ASTM Internacional.

[2] Associação Brasileira de Normas Técnicas (1989), NBR 7353: Soluções aquosas. Determinação do pH com eletrodos de vidro. Rio de Janeiro: ABNT.

[3] Waddel, W. J. and Bates, R. G. (1969), Intracellular pH. Physiological Reviews, 49: (2), USA.

[4] Buck, P. R. S.; Rondinini, K. A.; Convington, G. K. F.; Baucke, M. A. C.; Brett, M. F.; Camões, J. T. M.; Milton, T.; Mutssini, R.; Naumann, W. K.; Pratt, P.; Spitzer, S. and Wilson, G. (2002), Measurement of $\mathrm{pH}$ Definition, Standards, and Procedures. Internacional Union of Pure and Applied Chemistry, 74, 2169-2200.

[5]ANVISA (1999), Portaria no 304, de 08 de abril de 1999. Ministério da Saúde. Diário Oficial da União. Brasília. Disp. in: http://anvisa.gov.br/legis/resol/304_99.htm. Access in: dez. 2003.

[6] ANVISA (1999), Resolução no 362, de 29 de julho de 1999. Ministério da Saúde. Diário Oficial da União. Brasília. Disp. in: http://www.anvisa.gov.br/legis/resol/17_99rdc.ht m. Access in: dez. 2003.

[7] ANVISA (2003), Resolução no 210, de 04 de agosto de 2003. Ministério da Saúde. Diário Oficial da União. Brasília. Disp. in: http://elegis.bvs.br/leisref/public/showAct.php?id $=9619$. Access in: jul. 2004 .

[8] Associação Brasileira de Normas Técnicas (2001), NBR ISO IEC 17025: Requisitos Gerais para Competência de Laboratórios de Ensaios e Calibração. Rio de Janeiro: ABNT.

[9] BS (1984), BS 1647: pH measurement - part 2 Specification for reference value standard solutions and operational reference standard solutions. England and Wales: British Standard.
[10] BS (1993), BS 3145-1978: Specification for Laboratory $\mathrm{pH}$ meters. England and Wales: British Standard.

[11] JIS (1989), JIS Z 8805-1978: Glass Electrode for Measurement of pH. Japan.

[12] Deutsche Institut für Normung (1971), DIN 19260 : $\mathrm{pH}$ Measurement Definition of General Terms. Berlin, Germany: DIN.

[13] Deutsche Institut für Normung (1989), DIN 19263: Glass electrodes for $\mathrm{pH}$ Measurement. Berlin, Germany: DIN.

[14] Deutsche Institut für Normung (1994), DIN 19265: $\mathrm{pH}$ - Measurement; Supplementary $\mathrm{pH}$ Measuring Apparatus; Technical Requirements. Berlin, Germany: DIN.

[15] Deutsche Institut für Normung (2000), DIN 19266: Standard Buffer Solutions for Calibrating $\mathrm{pH}$ Measuring Equipment. Berlin, Germany: DIN.

[16] Deutsche Institut für Normung (1978), DIN 19267: pH Measurement; Technical Buffer Solutions, Preferably for the Calibration of Technical Measuring Installations. Berlin, Germany: Deutsche Institut für Normung..

[17] Deutsche Institut für Normung (1985), DIN 19268: Measurement of $\mathrm{pH}$ Value of Clear Aqueous Solutions. Berlin, Germany: DIN.

[18] Gosudarstvennye Standarty State Standard (1999), GOST8134-98: State System for Ensuring the Uniformity of Measurement: $\mathrm{pH}$ Scale for Aqueous Solutions. Russian: GOST.

[19] General Services Administration (1987), A-A53018: Buffer Solution, Standard (pH). USA: GSA.

[20] General Services Administration (1987), AA53206: Buffer Solution, Standard (pH 6,833 to 6,843). USA: GSA.

[21] JIS (1997), JIS K 0018: Reference Material - pH Standard Solution - Oxalate. Japan.

[22] Illingworth, J. A. (1981), A common source of error in $\mathrm{pH}$ measurement. The Biochemical Journal, 195, 259-262.

[23] Naumann, R.; Alexander-Weber, C.; Eberhardt, R.; Giera, J. and Spitzer, P. (2002), Traceability of $\mathrm{pH}$ measurements by glass electrode cells: performance characteristic of $\mathrm{pH}$ electrodes by multi-point calibration. Analytical and Bioanalytical Chemistry, 374, 778-786

[24] Karlsson, A. and Rosenvold, K (2002), The Calibration Temperature of $\mathrm{pH}$-glass Electrodes: Significance for Meat Quality Classification. Meat Science, 62, 497-501.

Received: July 29, 2005; Revised: September 05, 2005; Accepted: November 22, 2005. 